\title{
TAPHONOMY AND DEPOSITIONAL HISTORY OF AN UPPER CRETACEOUS TURTLE-BEARING OUTCROP FROM THE ADAMANTINA FORMATION, SOUTHWESTERN SÃO PAULO STATE
}

\author{
REINALDO J. BERTINI, RODRIGO MILONI SANTUCCI, \\ CARLOS EDUARDO VIEIRA TOLEDO \& MÍRIAM COSTA MENEGAZZO \\ NEPV, IGCE, UNESP, Av. 24 A/1515, Cx.P. 178, 13506-900, Rio Claro, SP, Brazil. \\ rbertini@rc.unesp.br; rmilonis@rc.unesp.br,cetoledo@rc.unesp.br;miriancm@rc.unesp.br
}

\begin{abstract}
The Adamantina Formation deposits (Upper Cretaceous) from the Bauru Basin, in southwestern São Paulo State, have revealed an extraordinary and well preserved assemblage of fossil turtles. In this contribution some new unique findings from these deposits and the Bauru Basin, are reported and discussed. Additionally, some peculiar sedimentary structures, as a bone fragment crossing two sedimentary layers, associated with the fossils, are described and biostratinomic considerations regarding these materials are made. The turtle remains from the studied outcrop have undergone short subaerial exposure and transport, being quickly buried. It was also verified that the time elapsed between these sedimentary episodes, in one of the samples, was almost instantaneous.
\end{abstract}

Key words: Testudines, Upper Cretaceous, Adamantina Formation, biostratinomy, Brazil.

RESUMO - Os depósitos da Formação Adamantina (Cretáceo Superior) da bacia Bauru no sudoeste do Estado de São Paulo, apresentam uma extraordinária e bem preservada quantidade de testudinos fósseis. Neste trabalho são comunicados novos e únicos achados provenientes desta região e da bacia Bauru. Adicionalmente, são descritas peculiares estruturas sedimentares, como um fragmento ósseo atravessando duas camadas sedimentares, associadas às amostras coletadas, e são tecidas considerações bioestratinômicas referentes a estes materiais. Os fósseis do afloramento estudado sofreram um curto período de exposição subaérea, pouco transporte e foram soterrados rapidamente. Constatou-se também, que o tempo transcorrido entre estes eventos deposicionais, em uma das amostras, foi praticamente instantâneo.

Palavras-chave: Testudines, Cretáceo Superior, Formação Adamantina, bioestratinomia, Brasil.

\section{INTRODUCTION}

The Upper Cretaceous rocks around the city of Pirapózinho, southwestern São Paulo State (Figure 1), have become famous, due to the large amount of turtle remains that have been unearthed there (Suarez, 1973; Bertini et al., 1993). Thus this region may rank as one of the most important areas for vertebrate fossils in southeastern Brazil.

These turtle-bearing rocks, informally called "tartaruguito" (Figures 1 and 2), were mentioned for the first time in the literature by Suarez (1969a, b), who described Testudines remains, recovered from that site. The deposits, in which the turtles are preserved, belong to the Adamantina Formation, Bauru Group, Upper Cretaceous (Suarez, 1973; Bertini et al., 1993).

Besides the holotype, numerous turtle remains, found in rocks from Pirapózinho City have been assigned to "Podocnemis" elegans Suarez, 1969, including skull, carapace, plastron, scapula, coracoid and limb bones from different specimens (Suarez, 1973; Bertini et al., 1993). There is also another turtle record, Roxochelys wanderleyi (Staesche, 1937) Price 1953, from Presidente Prudente and Pirapozinho cities, known by both carapace and incomplete skull (Suarez, 1973; Bertini, 1993; Bertini et al., 1993).

Kischlat et al. (1994) considered "Podocnemis" elegans as a different genus, erecting the new generic name Bauruemys to accommodate this taxon and probably also the remains regarded as "Podocnemis" brasiliensis (Staesche, 1937) Price, 1953. A taxonomic review of the turtles from the Bauru Basin will be published elsewhere. Here we follow Kischlat et al. (1994).

Fernandes \& Coimbra (2000) interpreted the deposits from Pirapózinho City (Figure 1), and adjacent areas, as part of meandering fluvial systems, which mainly include very fine to fine grained sandstones and claystones (Figure 2), corresponding to crevasse splays and proximal floodplains. 
Those authors also proposed a new designation, Presidente Prudente Formation, for those rocks, instead of using Adamantina Formation. However, the name Adamantina Formation is broadly used, regarding the Bauru Group. Its original definition (Soares et al., 1980) includes the deposits in Presidente Prudente and Pirapózinho cities (Figure 1). Hence this designation will be used here, for the sake of simplicity.

Unfortunately, there is no direct evidence concerning the age of the Adamantina Formation in the study area. According to Bertini et al. (2000), Gobbo-Rodrigues et al. (2000) and Santucci \& Bertini (2001), this geological unity is considered to be upper Campanian/lower Maastrichtian for deposits around Monte Alto and other places in the São Paulo State. On the other hand Dias-Brito et al. (2001) proposed a Turonian/Santonian age for these sediments. Since the Adamantina Formation represents widespread fluvial systems, they are able to migrate along time, so the proposed age for the Adamantina Formation, from other geological sections, can not be properly attributed to the Upper Cretaceous rocks of the Pirapózinho area (Figure 1).

The material (URC R $\bullet 71$ and URC R • 72, Figures 3-5) discussed here, was collected from a distinct bone-bed (Figure 2). The bones offer clues to the origin of the bonebed and the depositional dynamics of the section.

In this contribution we discuss new turtle findings from the Upper Cretaceous rocks around Pirapózinho City, with regard to the taphonomic and sedimentologic significances. These remains are an unique and not frequent kind of preservation, being for the first time recorded in the Bauru Group.

\section{DESCRIPTION}

The outcrop studied is located near the $\mathrm{km} 736$ of the old Sorocabana Railway, between the cities of Pirapózinho and Presidente Prudente (Figures 1 and 2; coordinates

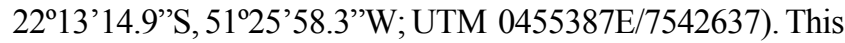
locality is characterized by grey mudstones, with thickness ranging from 1 to $1.5 \mathrm{~m}$ thick and extending about $1 \mathrm{~km}$ horizontally. These deposits define a low energy level for the Adamantina Formation. Above these mudstones there are rose to cream and white sandstones bodies, with mud matrix and cross bedding (Figure 2). These sandstones represent typical channel fluvial sedimentation.

The contact between the mudstone and sandstone layers is the level where the turtles came from. It shows specimens completely or partially preserved, with skulls, cervical vertebrae and appendicular bones, generally preserved within the shells (Figure 2). All these lithologies, especially the mudstones, are extremely rich in fossil vertebrates, mainly turtle remains (Podocnemididae). There are also some records of Titanosauria fragments and Mesoeucrodylia teeth, farther other Crocodylomorpha rests, including a vertebra collected from the above fine grained sandstone (Figure 2). However, different from Podocnemididae, these other taxa are not common and the collected remains are always fragmentary.

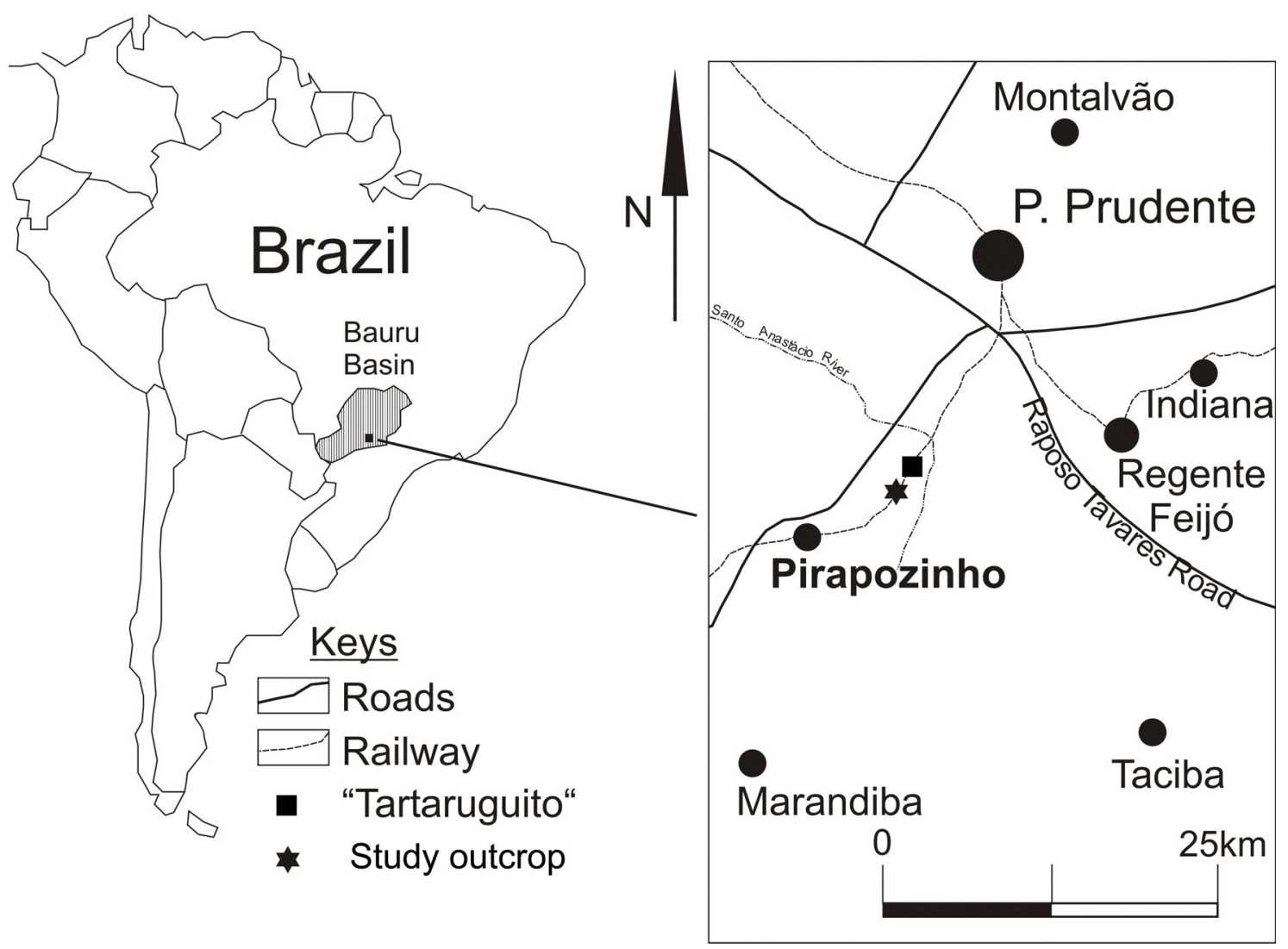

Figure 1. Location of the Bauru Basin in Southwestern São Paulo State, South America. The detailed map shows the approximate location of the "tartaruguito" (square) and the outcrop (star) studied in this paper with nearby cities. 
The turtle remains, from the Pirapozinho City region, are attributable mainly to Bauruemys elegans, based on the morphology of the shells. Among the bone remains collected there have been identified three well preserved skulls, cervical vertebrae (some of them articulated), incomplete carapaces and plastrons, shoulder and pelvic girdle elements, and limb bones, including articulated manus and pes.

The main sample (URC R • 71) corresponds to a fine grained sandstone block measuring $20 \times 30 \mathrm{~cm}$, in which disarticulated carapace and plastron bones, probably from different individuals, are preserved (Figures 3-4). From the bottom to the top, this sample (URC R • 71) is composed by a massive mudstone bed (layer A in Figure 3), which changes through a depositional hiatus contact to a mainly massive very fine grained sandstone, interbedded with thin mudstone layers (layer B in Figures 3-4). The mudstone strata become gradually more abundant towards the top of the sandstone bed, which is $8 \mathrm{~cm}$ thick (layer B in the Figures 3-4). Other

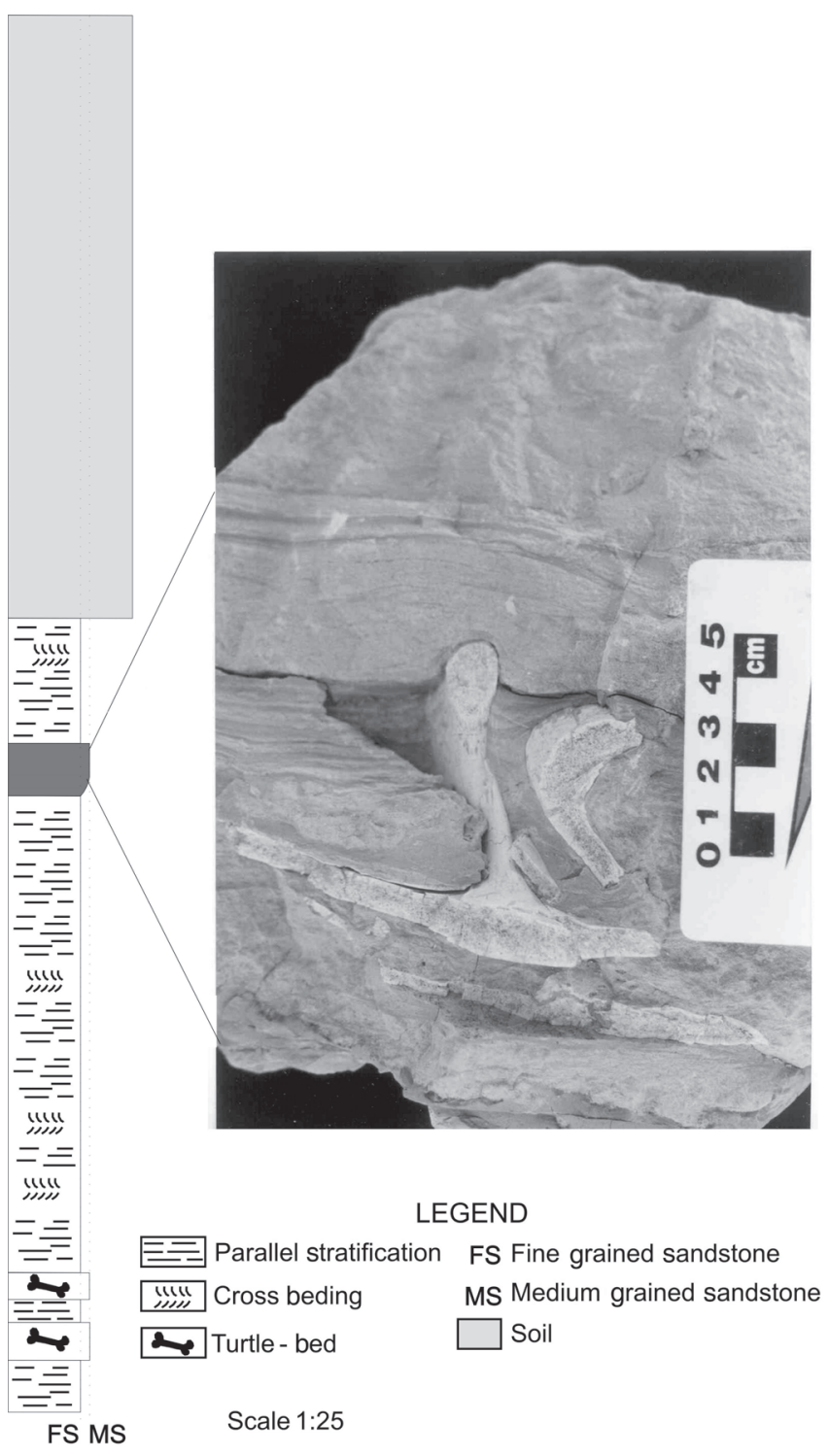

Figure 2. Stratigraphic section of the fossil locality, showing lithologies, sedimentary structures, fossils and the level where specimen UCR R $\cdot 71$ was collected, above the Turtle-Bed. depositional hiatus contacts the bottom of other massive very fine grained sandstone bed, interbedded with thin mudstone layers (doted line between the layers B and $\mathrm{C}$ in Figures 3-4). As far as it is possible to observe, this second sandstone bed shows less mudstone layers intercalated than the first one (layer $\mathrm{C}$ from figures 3-4).

The most striking feature of this material regards to the first sandstone bed, where remains of carapaces and plastrons are found in different levels (layer B in Figures 3-4). On the top of this first sandstone bed, it is observed a fragmented plastron, with remains of the anterior portion of the bridge, crossing the depositional hiatus, only partially covered by a thin mudstone layer, about $1 \mathrm{~mm}$ thick (doted lines and arrow between $\mathrm{B}$ and $\mathrm{C}$ layers in the Figures 3-4). This bone has been completely buried by the second sandstone bed (layer $\mathrm{C}$ in the Figures 3-4).

A second sample (URC R • 72) comprises a massive sandstone interbedded with mudstone layers. It includes fragmentary carapaces and plastrons, which are either parallel or perpendicular to the bedding (Figure 5).

\section{DISCUSSION}

The turtle fossils are generally well preserved and mostly articulated. There is little evidence of transportation or crushing and the internal cavity of the shells are usually filled in with the same sedimentary material found around.

The locality of "Turtle Cemitery", Santa Lucia Formation, early Paleocene from Bolívia (Broin, 1991) is similar, in some aspects, to Pirapozinho City outcrops. Broin (1991) considers this Bolivian deposit as corresponding to a dry pool.

The doted lines between layers $\mathrm{B}$ and $\mathrm{C}$ in the figures 3 and 4 (URC R • 71) depict part of a bone between two sedimentary episodes. The first episode has almost buried the bone completely and its epiphysis was just covered by a thin (about $1 \mathrm{~mm}$ thick) and homogeneous mudstone layer, at the final stage of this episode. At the time when sedimentation was happening, the bone was likely a small protuberance covered by mud, protruding from the ground (arrow in the Figures 3-4). The uppermost mudstone layer is uniform throughout the entire sample, seeming to cover the epiphysis of the bone homogenously, and there are not mudcrack evidences, which are common in subaerial mud deposits. Probably, this thin layer (doted line between layers B and C in the Figures 3-4) is the last one of this sedimentary episode. Then other depositional episode, which is marked by basal massive sandstone, completely covered the bone (layer $\mathrm{C}$ in Figures 3-4). The preservation of the thin mudstone layer, covering the bone, indicates that the depositional hiatus has been very short (doted line between layers B and C in the Figures 3-4). Otherwise, such layer would have been either completely destroyed by weathering or underwent some kind of cracking due to drying. Moreover the hypothesis of a short exposure period is also supported by the preservational state of the bone, which shows no fractures or evidences of abrasion.

Regarding the arrangement of the bone fragments in the matrix, some of them are crossing the layers, a few ones are almost reaching a perpendicular position to the bedding 
(Figure 5), as seen in specimen URC R • 72. This arrangement seems to be compatible with a quick loss of the flow energy, so that the fragmentary bones could not attain a more stable position, to the bedding, within the mud flow.

The presence of complete skulls, articulated limb bones including manus and pes, and the absence of abrasion marks, indicate that these turtles underwent short transportation. Additionally, the set of recovered bones, also support this interpretation.

Voorhies (1969) and Behrensmeyer (1975) demonstrated, through hydrodynamic studies, that some bones are more easily carried out than others by a water flow. However, the relationship between the set of collected bones, and transportation degree, is not that simple. For example, Blob (1997) demonstrated that dispersion potentials of turtle and mammal elements, could not be applied to all terrestrial vertebrates, or even all substrates. Among turtle elements, besides probably fragments of other vertebrates of intermediated size, and derived morphology, there are no uniform interactions with the botton boundary layer. It includes the initial orientation with respect to fluvial current, which confounds the density of the substratum. Almost the same situation occurs to mammalian skeletons (Blob, 1997). The turtle elements, with highest dispersal potentials are atlas, sternum, and astragalus/calcaneum. The lowest ones are showed by metatarsal IV, fibula, and xiphiplastron (Table1; Blob, 1997).

The turtle elements collected in Pirapózinho City (Figure 1) area match in all hydrodynamic groups proposed by Blob (1997) (see Table1). Both carapace and plastron elements represent the highest number of collected remains. Additionally, vertebrae and limb bones show an intermediate frequency; skulls, manus and pes bones are the least common recovered from the outcrop. This kind of arrangement parallels the proportion found in complete turtle skeletons and therefore indicates little transportation. The well preserved bones exhibit no evidence of parallel fractures in the long bone diaphysis, indicative of weathering (sensu Behrensmeyer, 1978; Fiorillo, 1988).

Behrensmeyer (1978) considers that small animals appear to weather more rapidly than large ones. In addition, Brand et al. (2003), studying specifically the taphonomy of freshwater turtles, concludes that the sequence of disarticulation of different bones varies, though there are some trends. These authors observed that head, neck, limbs and tail disarticulate early, while shell take the longest to fragment, beginning with carapace, plastron almost always being the last portion to become separated. The above information, combined with the lack of weathering on bones and the articulation of some skeletal elements, suggests a relatively short period of subaerial exposure for the assemblage.

The majority of the long bone fragments collected from the Pirapózinho City region, show perpendicular fractures (Figure 5), as seen in specimen URC R • 72, which are more likely to be produced in bones. After they suffered significant change, for example permineralization. Spiral or helical fractures indicate the bone was broken when fresh (Fiorillo, 1988, 1991; Lyman, 1994). Therefore this assemblage experienced little post mortem damage.

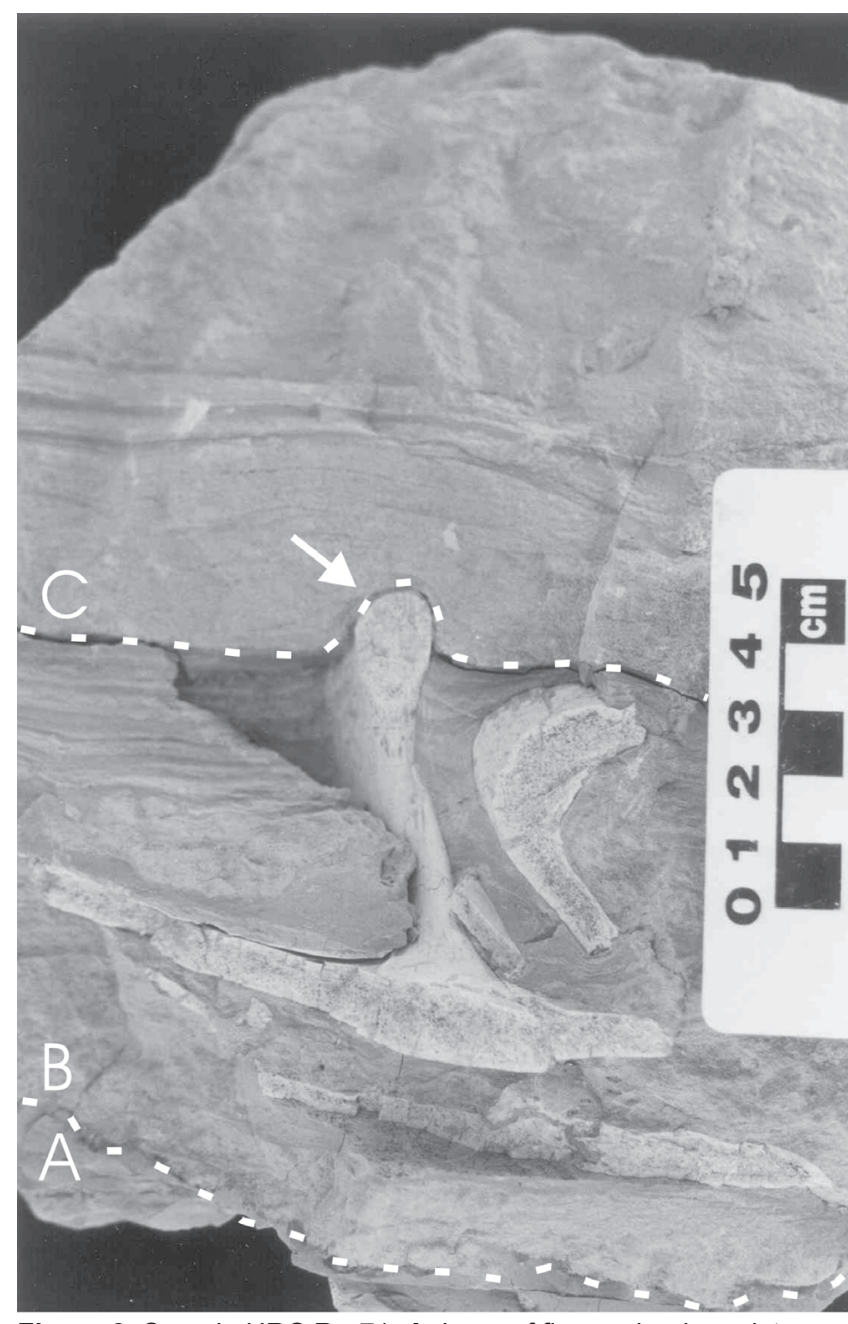

Figure 3. Sample URC R • 71. A, layer of fine grained sandstones; $\mathbf{B}$, intercalations of fine grained sandstones and mudstones where the majority of the bone remains are concentrated; C, layer with intercalations of fine grained sandstones and mudstones. A fragmented plastron, with remains of the anterior portion of the bridge, cross the depositional hiatus and is partially covered by a thin mudstone layer (arrow), about $1 \mathrm{~mm}$ thick.

\section{CONCLUSIONS}

The unusual mode of preservation of the turtle-bearing rocks from Pirapózinho City region provides a rare opportunity to establish the relative time elapsed between two fluvial sedimentary episodes, thus furnishing additional information about the depositional dynamics within a restricted part of the rock unit.

In the specimen URC R • 71, the depositional hiatus was instantaneous (Figures 3-4), under a geologically viewpoint, probably not more than few days. However it is necessary to keep in mind that it could not be a general pattern for the Adamantina Formation.

The articulation degree, frequency, absence of erosional marks, fracturing pattern, and the arrangement of the bones within the matrix, indicate the turtle remains had undergone a short period of subaerial exposure and were buried close to the source area. 
The good preservation of the remains discussed here, especially in URC R • 71, suggests a probable lack of scavenging during the taphonomic processes involved in their burial.

At the moment, it is not possible to determine what caused such a great availability of carcasses for burial. However, available evidence suggests that these turtles lived near the margins of oxbow lakes or meandering rivers.

\section{ACKNOWLEDGMENTS}

We are grateful to the student Pablo Xavier do Prado, (UNESP-Rio Claro), who helped to prepare the specimens to this study. We are also very grateful to the reviewers, especially Anthony R. Fiorillo, whose criticism and suggestions greatly improved this contribution.

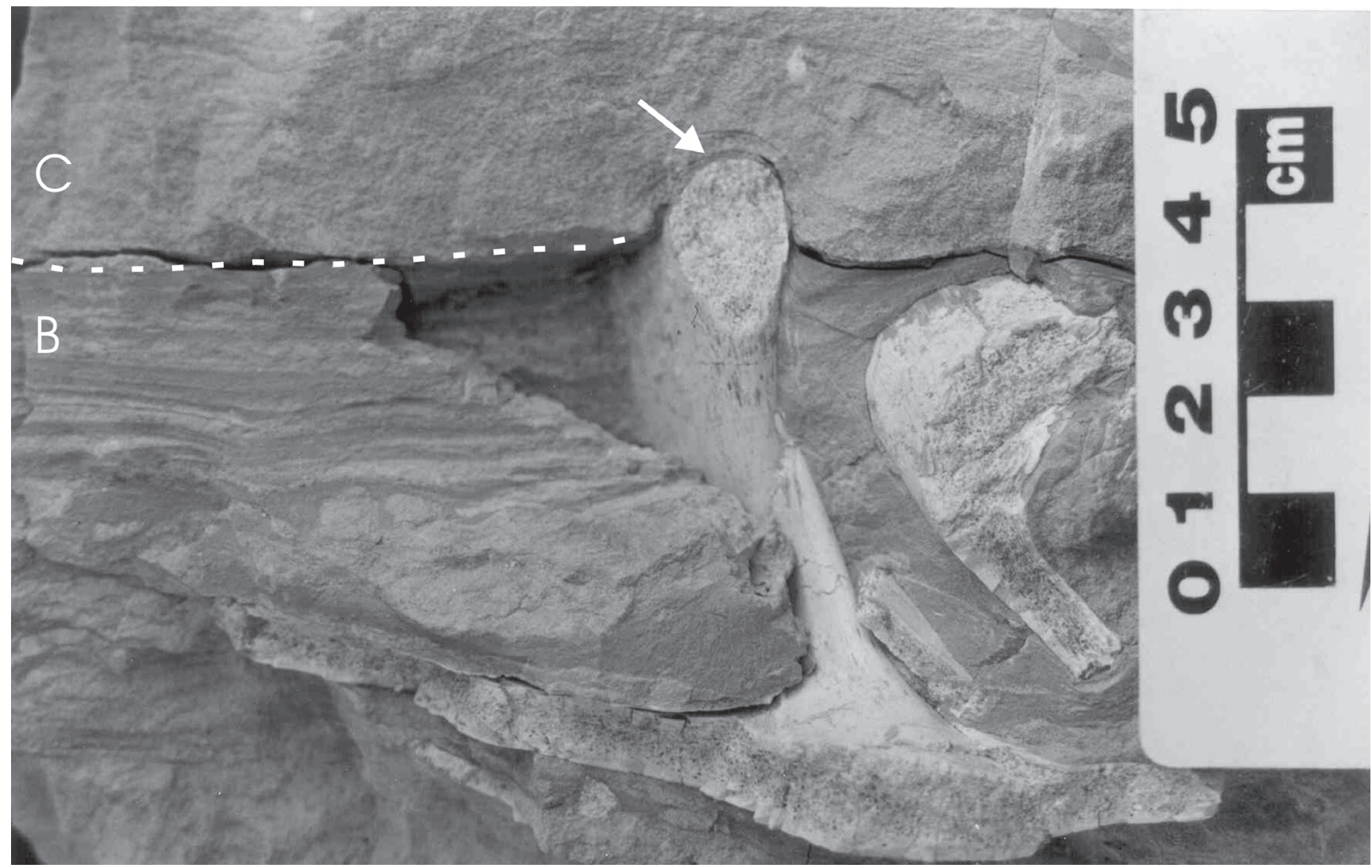

Figure 4. Detail of the fossil specimen (URC R • 71) pictured in the Figure 3. Symbols as in Figure 3.

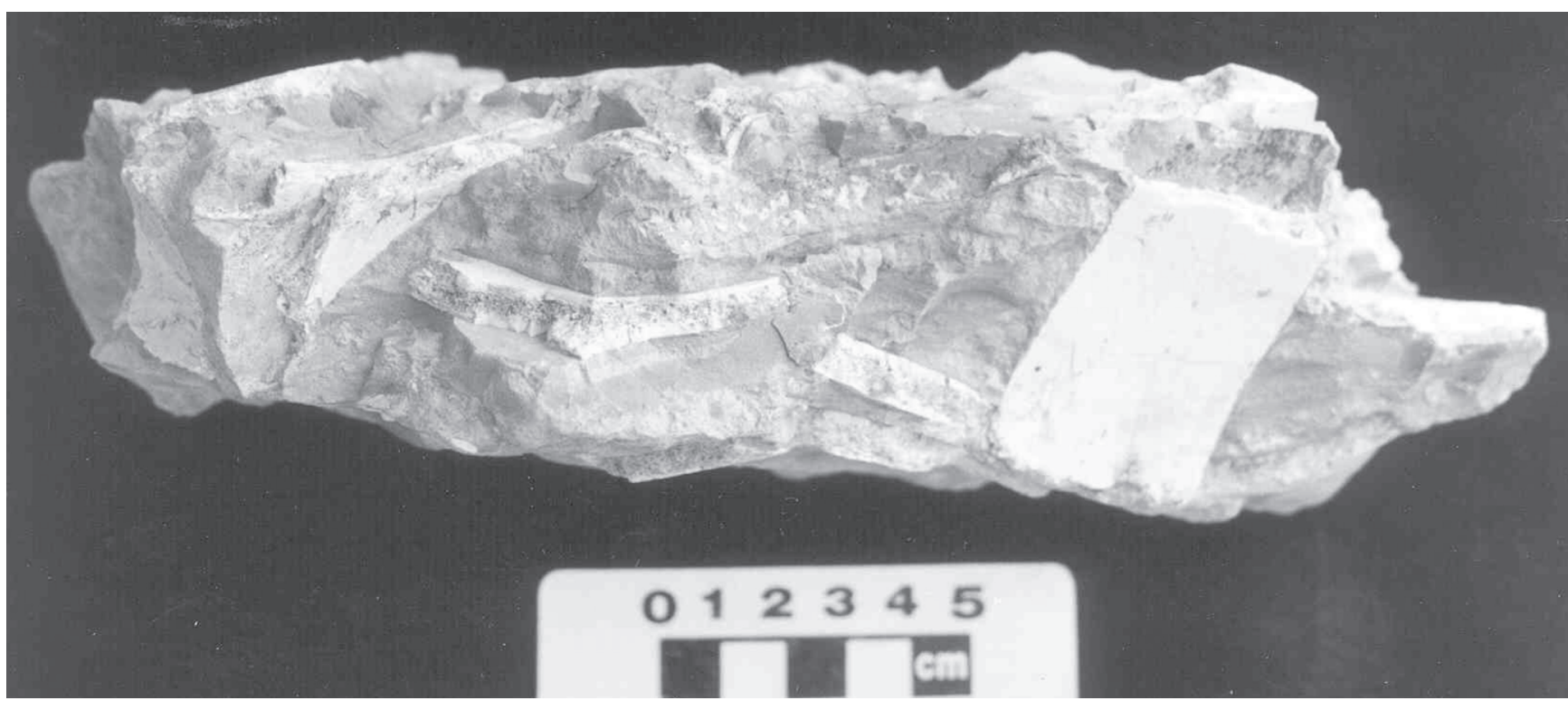

Figure 5. Sample URC R $\bullet 72$ showing massive fine grained sandstone with mudstone interbeds, and fragmentary carapaces and plastrons, either parallel or perpendicular to the subtle and almost indistinguishable sedimentary layers. Scale bar $=5 \mathrm{~cm}$. 
Table1. Hydrodynamic scheme for soft-shelled turtle elements. Skeletal remains are listed in order of increasing dispersion velocity, except in the Variable Dispersal column (from Blob, 1997).

\begin{tabular}{|c|c|c|c|}
\hline Early Dispersal & Intermediate Dispersal & Late Dispersal & Variable Dispersal \\
\hline Atlas & Hyoplastron & Metatarsal IV & Skull \\
\hline Sternum & Cervical Vertebrae & Fibula & Posterior Coastal \\
\hline \multirow[t]{9}{*}{ Astragalus/Calcaneum } & Humerus & Xiphoplastron & Nucal \\
\hline & Epiplastron & & Anterior Coastal \\
\hline & Lower Jaw & & Pedal Ungual Phalanx \\
\hline & Radius/UIna & & Hyoplastron \\
\hline & Entoplastron & & Femur \\
\hline & Tibia & & Scapulocoracoid \\
\hline & Pedal Phalanx & & \\
\hline & Neural & & \\
\hline & Pelvis & & \\
\hline
\end{tabular}

\section{REFERENCES}

Behrensmeyer, A.K. 1975. The taphonomy and paleoecology of Plio-Pleistocene vertebrate assemblages East of Lake Rudolf, Kenya. Bulletin of the Museum of Comparative Zoology, 146:473-577.

Behrensmeyer, A.K. 1978. Taphonomic and ecology information from bone weathering. Paleobiology, 4(2):150-162.

Bertini, R.J. 1993. Paleobiologia do Grupo Bauru, Cretáceo Superior continental da bacia do Paraná, com ênfase em sua fauna de amniotas. Programa de Pós-Graduação em Geologia, Universidade Federal do Rio de Janeiro, Tese de Doutoramento, 493 p.

Bertini, R.J.; Marshall, L.G.; Gayet, M.; Brito, P.M. 1993. The vertebrate fauna from the Adamantina and Marília formations, Upper Cretaceous of the Paraná Basin, Southeast Brazil. Neues Jahrbuch fur Mineralogie, Geologie und Paleontologie, 188(1):71-101.

Bertini, R.J.; Santucci, R.M.; Ribeiro, L.C. B.; Arruda-Campos, A.C. 2000. Aeolosaurus (Sauropoda, Titanosauria) from Upper Cretaceous of Brazil. In: JORNADAS ARGENTINAS DE PALEONTOLOGIA DE VERTEBRADOS, 16, 2000. Resumenes, San Luís, p. 6.

Blob, R.W. 1997. Relative hydrodynamic dispersal potential of soft-shelled turtle elements: implications for interpreting skeletal sorting in assemblages of non-mammalian terrestrial vertebrates. Palaios, 12 (2):151-164.

Brand, L.R.; Hussey, M.; Taylor, J. 2003. Taphonomy of freshwater turtles: decay and disarticulation in controlled experiments. Journal of Taphonomy, 1(4):233-245.

Broin, F. de 1991. Fossil turtles from Bolívia. Revista Técnica Yacimientos Petroliferos Fiscales de Bolivia, 12(3-4):509-514.

Dias-Brito, D.; Musacchio, E.A.; Castro, J.C.; Maranhão, M.S.A.S.; Suárez, J.M.; Rodrigues, R. 2001. Grupo Bauru: uma unidade continental do Cretáceo no Brasil - concepções baseadas em dados micropaleontológicos, isotópicos e estratigráficos. Revue de Paléobiologie, 20:245-304.

Fernandes, L.A. \& Coimbra, A.M. 2000. Revisão estratigráfica da parte oriental da bacia Bauru (Neo-Cretáceo). Revista Brasileira de Geociências, 30(4):717-728.
Fiorillo, A. R. 1988. Taphonomy of Hazard Homestead Quarry (Ogllala Group), Hitchcock County, Nevada. Contributions to Geology, University of Wyoming, Special Paper, 26:57-97.

Fiorillo, A.R. 1991. Taphonomy and depositional setting of Careless Creek Quarry (Judith River Formation), Wheatland County, Montana, USA. Paleogeography, Paleoclimatology, Paleoecology, 81(3/4):281-311.

Gobbo-Rodrigues, S.G.; Petri, S.; Coimbra, J.C.; Bertini, R.J. 2000. Bioestratigraphic correlations between Bauru, Neuquén and Congo basins, using non-marine ostracodes. In: SIMPÓSIO BRASILEIRO DE PALEOARTROPODOLOGIA, 1, 2000. Resumos, Ribeirão Preto, USP, p. 87-88.

Kischlat, E.E.; Barberena, M.C.; Timm, L.L. 1994. Considerações sobre a queloniofauna do Grupo Bauru, Neo-Cretáceo do Brasil: In: SIMPÓSIO SOBRE O CRETÁCEO DO BRASIL, 3, 1994. Boletim, Rio Claro, UNESP, p. 105-107.

Lyman, R. L. 1994. Vertebrate Taphonomy. Cambridge, Cambridge University Press, 524 p.

Santucci, R. M. \& Bertini, R. J. 2001. Distribuição paleogeográfica e biocronológica dos titanossauros (Saurischia, Sauropoda) do Grupo Bauru, Cretáceo Superior do Sudeste brasileiro. Revista Brasileira de Geociências, 31(3):299-306.

Soares, P.C.; Landim, P.M.B.; Fulfaro, V.J.; Sobreiro Neto, A.F. 1980. Ensaio de caracterização estratigráfica do Cretáceo no Estado de São Paulo: Grupo Bauru. Revista Brasileira de Geociências, 10(3):177-185.

Suarez, J.M. 1969a. Um quelônio da Formação Bauru. Boletim do Departamento de Geografia - Faculdade de Filosofia Ciências e Letras de Presidente Prudente, 2:35-54.

Suarez, J.M. 1969b. Um quelônio da Formação Bauru. In: CONGRESSO BRASILEIRO DE GEOLOGIA, 23, 1969. Anais, Salvador, UFBA, p. 167-176.

Suarez, J.M. 1973. Contribuição à Geologia do extremo Oeste do Estado de São Paulo. Faculdade de Filosofia, Ciências e Letras de Presidente Prudente, Tese de Doutoramento, $91 \mathrm{p}$.

Voorhies, M.R. 1969. Taphonomy and population dynamics of an early Pliocene vertebrate fauna. Contributions to Geology, University of Wyoming, 1:1-69.

Received in January, 2005; accepted in February, 2006. 